were far from complete and the workshops and laboratories only outlined. These handicaps were well overcome; besides the teaching staffs transferred, many new heads of departments and lecturers were appointed; and at present the full-time staff numbers 82 with 180 part-time instructors. The number of students for the session reached 6,842 . Association with the four institutes mentioned and various junior schools has been achieved without a hitch.

We notice a general building course, three foreign language clubs which have run successfully on selfgoverning lines, and classes on milk technology, beekeeping and glass-blowing. Biology on Saturday mornings has attracted local teachers, who have maintained a high standard of work and steady attendance. The success of the College and the demands for its teaching are a credit to all concerned. It may well be a model for a substantial advance in education elsewhere.

\section{Progress in Education}

Education in the United States is well served by several periodicals. The issue for February last of School Life, the official organ of the U.S. Office of Education, is well illustrated and full of live discussion of controversial issues, while it illustrates the enterprise of educational authorities. The science department of Dover High School in Ohio has leased twenty-five acres of potential flood land which are to be used as a field laboratory for the study of ecology and the management of streams and ponds. It is suggested that the Decennial Census, which is due in April, might be discussed in schools, as it has a very wide scope and will include housing for the first time. School and Society, February 17, begins with a good article on "The Teacher Pupil Relationship in a Democracy" and ends with a striking one on "Vocabulary and Success in College". Vocabulary and style are, in fact, of great importance for success in life. Max Müller was not well informed when he put down the words used in a country parish as less than 300 ; but the rustic world, which has its own expert information to give, is still hampered by its incoherence, and education should be always enlarging the effective use of language. On the elementary side, it is to cost Great Britain, according to the latest yearly estimate, well over 36 million sterling. Forty years since, men of science were below the educated standard in books and journalism; now they are distinguished for good writing, which is appreciated by the general public. This is particularly needed in science, since discoveries are exaggerated and misstated by fluent 'stunt' writers who popularize without adequate knowledge.

\section{Announcements}

Dr. W. Sucksmith, lecturer in physics in the University of Bristol, has been appointed to the chair of physics in the University of Sheffield, in succession to Prof. S. R. Milner, who is retiring at the end of the present session.
THE following appointments and promotions in the Colonial Service have recently been made: D. C. Edwards, agricultural officer, senior agricultural officer, Kenya ; E. T. Holmes, senior agricultural officer, Nigeria, senior agricultural officer, Sierra Leone; G. W. Nye, senior botanist, deputy director of agriculture, Uganda; A. H. W. Weir, conservator of forests, deputy chief conservator of forests, Nigeria.

IN commemoration of the centenary of the founda. tion of King's College Hospital a tablet was unveiled on April 17 at Strand House, Portugal Street, London, which showed the site occupied by the hospital from 1839 until 1913.

THE Rockefeller Foundation has made a grant of

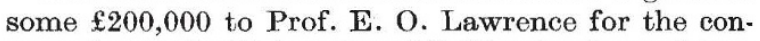
struction at the University of California of a cyclotron of $184 \mathrm{in}$. diameter. The total weight of this apparatus will be about 5,000 tons and it will take about three years to build. Such a machine is expected to produce deuterons of $16^{8}$ volts energy.

Dr. Philip E. Sмiтh, professor of anatomy at the College of Physicians and Surgeons, Columbia University, was elected president of the American Association of Anatomists at the fifty-sixth annual convention held at Louisville, Kentucky, on March 21.

To encourage the preparation of papers by students of fuel technology, the Council of the Institute of Fuel has decided to make an annual award of a medal, together with a prize consisting of books and/or instruments to the value of $£ 5$. A copy of the rules governing the award can be obtained from the Secretary, Institute of Fuel, 30 Bramham Gardens, London, S.W.5.

The Egypt Exploration Society, of 2 Hinde Street, Manchester Square, London, W.1, and 1450 Broadway, New York, announces that on September 1 it will publish in two volumes "Temples of Armant" by Sir Robert Mond and Oliver H. Myers. Lady Mond has generously made it possible to finish the work of the Mond Expedition in the manner originally contemplated, and the last three years work is being published in two memoirs, "Temples of Armant, a Preliminary Survey", and "Cemeteries of Armant II and a Saharan Culture". Each work will be published in two volumes, one of text and one of plates (some of which will be coloured), in the same style as "Cemeteries of Armant I".

REFERENCE was made in Nature of May 4, p. 701, to the amalgamation under the style of Newton and Co., Ltd., of two well-known firms of the name of Newton. It should have been stated that the combined business is now being carried on at 72 Wigmore Street, London, W.1.

ERratum.-In the letter entitled "Rhythmical Impedance Changes in the Trout's Egg" in Nature, May 11, p: 744, line 11, for "sodium nitride" read "sodium azide". 